\title{
Greater Sage-Grouse (Centrocercus urophasianus) select habitat based on avian predators, landscape composition, and anthropogenic features
}

\author{
Jonathan B. Dinkins, ${ }^{1 *}$ Michael R. Conover, ${ }^{1}$ Christopher P. Kirol, ${ }^{2}$ Jeffrey L. Beck, ${ }^{2}$ \\ and Shandra Nicole Frey ${ }^{1}$ \\ ${ }^{1}$ Department of Wildland Resources, Utah State University, Logan, Utah, USA \\ 2 Department of Ecosystem Science and Management, University of Wyoming, Laramie, Wyoming, USA \\ * Corresponding author: jondinkins@hotmail.com
}

Submitted December 20, 2013; Accepted September 5, 2014; Published November 5, 2014

\begin{abstract}
Prey species minimize the risk of predation directly by avoiding predators and indirectly by avoiding risky habitat. Habitat loss and fragmentation have been prevalent in Greater Sage-Grouse (Centrocercus urophasianus; hereafter "sage-grouse") habitat, which has necessitated a better understanding of mechanisms driving habitat use. Using multinomial logistic regression, we compared landscape attributes and anthropogenic features (indirect mechanisms) and densities of avian predators (direct mechanisms) among 792 sage-grouse locations (340 nests, 331 early brood, and 121 late brood) and 660 random locations in Wyoming, USA, in 2008-2011. Anthropogenic features included oil and gas structures, communication towers, power lines, roads, and rural houses; and landscape attributes included a normalized difference vegetation index (NDVI), topographic ruggedness, the proportion of big sagebrush (Artemisia spp.), and proximity and proportion variables for forested and riparian habitats. Sage-grouse locations were best described with models that included multiple habitat variables and densities of small, medium, and large avian predators. Thus, both indirect and direct mechanisms of predator avoidance were employed by sage-grouse to select habitat and presumably lower their exposure to predation and nest predation. At all reproductive stages, sage-grouse selected flatter locations with a greater proportion of big sagebrush, a higher NDVI, and lower densities of oil and gas structures. Nest locations had a lower density of major roads and were farther away from riparian habitat; early-brood locations had a lower density of power lines and were closer to rural houses; and late-brood locations were closer to riparian habitat. The magnitudes of direct and indirect avoidance by sage-grouse hens were dependent on a sagegrouse's reproductive stage. Differential habitat use of female sage-grouse relative to predation risk and food availability was a means for sage-grouse hens to lower their risk of predation and nest predation, while using habitat to meet their energetic requirements and those of their chicks.
\end{abstract}

Keywords: brood-site selection, corvid, habitat use, Greater Sage-Grouse, nest-site selection, predator avoidance, predation risk, raptor

Centrocercus urophasianus selecciona el hábitat basado en las aves depredadoras, la composición del paisaje y las características antropogénicas

\section{RESUMEN}

Las especies de presa minimizan el riesgo de depredación evitando directamente a los depredadores e indirectamente evitado los hábitats riesgosos. La pérdida de hábitat y la fragmentación han sido determinantes en el hábitat de Centrocercus urophasianus, lo que ha hecho necesaria una mejor comprensión de los mecanismos que determinan el uso del hábitat. Usando regresión logística multinomial, comparamos los atributos del paisaje y las características antropogénicas (mecanismos indirectos) y la densidad de aves depredadoras (mecanismos directos) entre 792 localizaciones de C. urophasianus (340 nidos, 331 crías recientes y 121 crías tardías) y 660 localizaciones al azar en Wyoming, entre 2008 y 2011. Las características antropogénicas incluyeron estructuras de petróleo y gas, torres de comunicación, tendidos eléctricos, caminos y casas rurales; y los atributos del paisaje incluyeron el índice normalizado de diferencia de vegetación (NDVI), rugosidad topográfica, proporción de especies de Artemisia y proximidad y proporción de hábitats boscosos y ribereños. Las localizaciones de $C$. urophasianus fueron mejor descritas con modelos que incluyeron múltiples variables de hábitat y densidad de aves predadoras pequeñas, medianas y grandes. Así, $C$. urophasianus usó mecanismos indirectos y directos de evasión de los depredadores para seleccionar los hábitats y bajar presumiblemente su exposición a la depredación y a la depredación de los nidos. En todos los estadios reproductivos, C. urophasianus seleccionó localizaciones más planas con una mayor proporción de especies de Artemisia, NDVI más elevado y densidades más bajas de estructuras de petróleo y gas. Las localizaciones de los nidos tuvieron menor densidad de caminos principales y estuvieron más alejadas de los hábitats ribereños; las localizaciones 
de las nidadas tuvieron menor densidad de tendidos eléctricos y estuvieron más cercanas a casa rurales; y las localizaciones de las nidadas tardías estuvieron más cerca a los hábitats ribereños. Las magnitudes de la evasión directa e indirecta por parte de los individuos de C. urophasianus dependieron del estadio reproductivo de $C$. urophasianus. Los diferentes usos de hábitat de las hembras de C. urophasianus con relación al riesgo de depredación y a la disponibilidad de alimentos fue aprovechada por los individuos de C. urophasianus para bajar su riesgo de depredación y la depredación de los nidos, durante el uso del hábitat para alcanzar los requerimientos energéticos de los adultos y los pichones.

Palabras clave: aves depredadores, Centrocercus urophasianus, córvido, evasión del depredador, rapaz, riesgo de depredación, selección de sitio de la nidada, selección de sitio del nido, uso de hábitat

\section{INTRODUCTION}

Predator avoidance behaviors influence habitat selection indirectly by reducing the use of risky habitats (habitats correlated with higher risk of predation) or directly by avoiding predators once they are seen (Lima 1998, Verdolin 2006, Cresswell 2008, Dinkins et al. 2012). Both indirect and direct mechanisms of predator avoidance are connected with an animal's perceived risk of predation (Cresswell 2008, Martin and Briskie 2009). For example, the risk of predation taken by male Red-breasted Nuthatches (Sitta canadensis) and White-breasted Nuthatches (S. carolinensis) to feed females on nests was lower in the presence of House Wrens (Troglodytes aedon) and Sharp-shinned Hawks (Accipiter striatus), which indicates direct avoidance of predators (Ghalambor and Martin 2000). Greater Sage-Grouse (Centrocercus urophasianus; hereafter "sage-grouse") use habitat with lower densities of avian predators (Dinkins et al. 2012). Dinkins et al. (2012) suggested that the potential mechanism for this pattern was direct predator avoidance, but the pattern could also be explained in part as avoidance of habitat correlated with higher avian predator densities (e.g., oil and gas structures, power lines, forested habitat, etc.).

Anthropogenic features can be used as perches or nest structures by avian predators or can be associated with food subsides. American Kestrels (Falco sparverius; hereafter "kestrel"), Common Ravens (Corvus corax; hereafter "raven"), Golden Eagles (Aquila chrysaetos), Ferruginous Hawks (Buteo regalis), Red-tailed Hawks (Buteo jamaicensis), and Swainson's Hawks (Buteo swainsoni) use power lines for perching or nesting and areas around power lines for foraging (Lammers and Collopy 2007, Prather and Messmer 2010, Slater and Smith 2010, Coates et al. 2014, Howe et al. 2014). Road-killed animals also attract mammalian and avian predators (Bradley and Fagre 1988, Boarman 1993, Boarman et al. 1995, Frey and Conover 2006). Several studies have demonstrated that sagebrush-obligate birds, including Brewer's Sparrows (Spizella breweri), Sagebrush Sparrows (Artemisiospiza nevadensis), Vesper Sparrows (Pooecetes gramineus), and sage-grouse are negatively associated with oil and gas infrastructure (Aldridge 2005, Walker et al. 2007, Doherty 2008, Carpenter et al. 2010, Holloran et al. 2010, Gilbert and Chalfoun 2011). In addition, sage-grouse avoid power lines (Hanser et al. 2011) and roads (Holloran 2005, Aldridge and Boyce 2007). Thus, sagebrush birds, including sage-grouse, may avoid man-made features to indirectly reduce predation risk.

In addition to avoiding tall man-made structures (structures $>2 \mathrm{~m}$ tall) and roads, prey species including sage-grouse may indirectly avoid avian predators by avoiding other landscape attributes that represent riskier habitat, such as riparian areas, coniferous forests, and rough terrain. In northeastern Wyoming, USA, Doherty et al. (2010) found that sage-grouse selected nesting habitat with lower terrain roughness and percent cover of conifer, grassland, and riparian habitat; they also found that sagegrouse selected areas with a greater density of sagebrush (Artemisia spp.) at the scale of 100 to $350 \mathrm{~m}$ compared with random locations within sagebrush. Greater density of sagebrush at relatively large spatial extents may reduce the foraging efficiency of visual predators. Reduced predation has the potential to increase not just sagegrouse adult survival but also nest success. For example, Brewer's Sparrows nesting in areas with greater shrub cover and a greater density of vacant potential nest sites had better nest success (Chalfoun and Martin 2009).

A better understanding of habitat quality and mechanisms driving habitat use is a key component of conservation of sage-grouse, a species of conservation concern (Braun 1998, Schroeder et al. 2004, Connelly et al. 2011). Little research has explicitly compared the relative importance of indirect vs. direct predator avoidance mechanisms in relation to the use of habitat by prey species, which could have implications for management recommendations. Sage-grouse may avoid avian predators indirectly by avoiding landscape attributes or anthropogenic features that might attract avian predators or directly by observing them; however, it is more likely that sagegrouse use both indirect and direct means of avoiding predators. We used sage-grouse as a model prey species to test the importance of both indirect and direct predator avoidance. From 2008 to 2011, we recorded avian predator densities and calculated distances from landscape attributes and anthropogenic features to radio-tagged sagegrouse hens to determine the importance of direct and indirect predator avoidance by sage-grouse hens. For 
precocial species such as sage-grouse, predator avoidance may differ among reproductive stages (Ghalambor and Martin 2000). Thus, we also evaluated habitat use of sagegrouse females during two reproductive stages, nesting and brood-rearing. We hypothesized that sage-grouse primarily would avoid nesting and raising their chicks in areas with high densities of avian predators and secondarily would avoid landscape attributes and anthropogenic features that posed a greater risk of predation. We also hypothesized that sage-grouse hens would respond to multiple predator species by always avoiding avian predators, which are a threat to adult hen survival during all reproductive stages, but by avoiding predators that are threats to just nests and chicks only during those reproductive stages. Finally, we predicted that hens would use more productive, but riskier, riparian habitat only when chicks were less vulnerable to predation.

\section{METHODS}

\section{Study Area}

Our study was conducted at 12 sites in southwestern and south-central Wyoming, USA. Holloran and Anderson (2005) found that $93 \%$ of 415 observed nests were within $8.5 \mathrm{~km}$ of leks at which females were captured in central and southwestern Wyoming. Thus, our eight sites in southwestern Wyoming (Lincoln, Sweetwater, and Uinta counties) were $16 \mathrm{~km}$ in diameter, approximately centered around leks where hens were captured. The four sites in southcentral Wyoming (Carbon and Sweetwater counties) were $24 \mathrm{~km}$ in diameter, because sage-grouse were captured at several nearby leks over a larger area. Sites were chosen to provide a representation of overall sage-grouse nesting habitat in southern Wyoming, with a variety of land uses and topographic features. Elevation ranged from 1,950 $\mathrm{m}$ to $2,600 \mathrm{~m}$. Most of the area within our sites was federally owned and administered by the Bureau of Land Management, with a small percentage of private lands. Domestic sheep and cattle grazing were the dominant land uses in our sites. All sites had anthropogenic development, which consisted mostly of unimproved four-wheel drive roads. Conventional natural gas, coalbed methane natural gas, and/or conventional oil extraction activities were present in six (50\%) of our sites; mean well density among all sites was $0.12 \pm 0.22 \mathrm{SD}$ wells $\mathrm{km}^{-2}$ (minimum-maximum $=0.00$ 0.64 wells $\mathrm{km}^{-2}$ ).

The landscape at all sites was dominated by sagebrush; Wyoming big sagebrush (Artemisia tridentata wyomingensis) and mountain big sagebrush (A. t. vaseyana) were the most common. Black sagebrush $(A$. nova) and little sagebrush (A. arbuscula) were found on exposed ridges. Other common shrub species included alderleaf mountain mahogany (Cercocarpus montanus), antelope bitterbrush (Purshia tridentata), chokecherry (Prunus virginiana), common snowberry (Symphoricarpos albus), greasewood (Sarcobatus vermiculatus), rabbitbrush (Chrysothamnus spp.), Saskatoon serviceberry (Amelanchier alnifolia), and spiny hopsage (Grayia spinosa). Isolated stands of juniper (Juniperus spp.) and quaking aspen (Populus tremuloides) were found at the higher elevations on north-facing hillsides.

\section{Sage-grouse Capture and Monitoring}

We monitored sage-grouse hens during nesting and brood-rearing from 2008 to 2011. Hens were captured, radio-tagged, and released in April of each year. We captured hens at night using all-terrain vehicles (ATVs), spotlights, and hoop-nets (Giesen et al. 1982, Wakkinen et al. 1992). Sage-grouse hens were fitted with 17.5-g or 22-g $(<1.5 \%$ body mass) necklace radio-collars (RI-2D, Holohil Systems, Carp, Ontario, Canada; or A4060, Advanced Telemetry Systems, Isanti, Minnesota, USA).

We located hens weekly with Communications Specialists receivers (R-1000, Communications Specialists, Orange, California, USA) and three-way Yagi antennas. Potential nests were identified with binoculars from $\sim 15$ $\mathrm{m}$ away by visually locating a radio-tagged hen under a shrub. Nests were verified by triangulating the hen under the same shrub from $>50$ m away or thoroughly searching the area of the potential nest when the hen was absent. We continued monitoring nests weekly until the nest hatched or failed.

We located the broods of radio-tagged hens weekly with binoculars from $\sim 15 \mathrm{~m}$ distance. Brood hens were identified either by visually detecting chicks or by observing hen behavior that indicated the presence of a brood (e.g., hesitation to flush, feigning injury, clucking). If there was evidence of at least one chick with a sage-grouse hen, we classified the hen as early brood (chicks $<4$ weeks of age) or late brood (chicks 4-8 weeks of age). Monitoring of broods continued for as long as possible, which was usually until the chicks were $3-8$ weeks posthatch, the hen lost her brood, the hen died, or the hen could no longer be located.

\section{Avian Predator Monitoring}

To quantify avian predators, we used standard distance sampling techniques (Ralph et al. 1995, Buckland et al. 2001, Thomas et al. 2010), which entailed counting all avian predators observed during point counts and recording their distance from the observer. Point counts were conducted at random and sage-grouse (nest, early brood, and late brood) locations. Random locations were selected from habitat dominated by sagebrush within $8 \mathrm{~km}$ of the leks where sage-grouse were captured. This was intended to quantify avian predator density in habitat available for use by sage-grouse (Dinkins et al. 2012). Within each year, random locations were $>2,000 \mathrm{~m}$ apart. 
Point counts at sage-grouse nests were established when hens had begun incubating; thus, we assumed that we detected raptors and corvids that were present when nests were initiated. For a detailed description of point count methods see Dinkins et al. (2012) and Dinkins (2013). All avian predator variables were calculated from the raw count data within effective detection radii (EDR) estimated with DISTANCE version 6.0 release 2 (Thomas et al. 2010), as specified in Dinkins et al. (2012). Thus, Buteo spp. hawk, Golden Eagle, Northern Harrier (Circus cyaneus; hereafter "harrier"), kestrel, Black-billed Magpie (Pica hudsonia; hereafter "magpie"), and raven densities were individually calculated within $450 \mathrm{~m}, 1,000 \mathrm{~m}, 350 \mathrm{~m}, 400$ $\mathrm{m}, 300 \mathrm{~m}$, and $600 \mathrm{~m}$, respectively, of each point count location (see Dinkins et al. 2012 for further details). We did not include other falcons or owls because they were rarely detected during point counts. Raw densities were standardized by the number of visits to each point count location and were log-transformed.

\section{Anthropogenic and Landscape Feature Variables}

We used ArcMap 10.0 (Esri, Redlands, California, USA) to calculate point count proximity (Euclidean distance) to anthropogenic features that could be used as perch or nest sites by avian predators or could provide food subsidies. We quantified the distance from each point count location to the nearest oil and gas structure (energy well, compressor station, transfer station, refinery, or other energy-extraction-related building), major road, any road type, communication tower, house, or power line. Densities of anthropogenic structures were calculated at four spatial extents $(0.27-\mathrm{km}, 0.54-\mathrm{km}, 1.00-\mathrm{km}$, and $3.00-\mathrm{km}$ radii) for oil and gas structures (number $\mathrm{km}^{-2}$ ), major roads $\left(\mathrm{km} \mathrm{km}^{-2}\right)$, all road types $\left(\mathrm{km} \mathrm{km}^{-2}\right)$, houses (number $\left.\mathrm{km}^{-2}\right)$, and power lines $\left(\mathrm{km} \mathrm{km}^{-2}\right)$. The four spatial extents were derived from previous research on sage-grouse (Holloran and Anderson 2005, Aldridge and Boyce 2007, Carpenter et al. 2010, Doherty et al. 2010, Aldridge et al. 2011, Hanser et al. 2011). Ongoing energy development was occurring in half of our sites, which required us to assess the dates that energy-related structures and roads were added or removed from the landscape.

In distance calculations, we included only oil and gas structures and roads that existed when each point count was conducted. We obtained information on oil and gas structures, including the date that construction started on the structure and the date when wells were plugged and abandoned (the date that the structure was removed), from the Wyoming Oil and Gas Conservation Commission (WOGCC; http://wogcc.state.wy.us). We verified the spatial location and existence of older structures with color aerial satellite imagery from summer 2006 and August 2009 obtained from the National Agriculture Imagery
Program (NAIP; U.S. Department of Agriculture 2010). Aerial imagery from NAIP is produced by the U.S. Department of Agriculture (USDA) on a 3-yr rotation; thus, we used WOGCC data and on-the-ground GPS units to map energy development that occurred after August 2009.

We used 2009 NAIP imagery to digitize the location of major roads, all roads, communication towers, and houses within a 5-km buffer around sites; roads constructed between August 2009 and September 2011 were mapped on the ground with GPS units. Major roads included paved roads, improved gravel roads, and railroads; all roads included major roads and all unimproved four-wheel drive roads. All transmission and distribution power lines within a $5-\mathrm{km}$ buffer around sites were mapped on the ground with GPS units; telephone lines not associated with a power line were included in power-line mapping.

Sage-grouse were likely to respond to many different types of anthropogenic structure in a similar manner (e.g., select locations farther away from all tall structures). Thus, we created two anthropogenic structure variables that represented the nearest: (1) distance to an oil and gas structure, communication tower, or house (WCH); and (2) distance to an oil and gas structure, communication tower, house, or power line (ANTH). This was in addition to distances from point count locations to individual types of anthropogenic structures.

Similarly to anthropogenic feature calculations, we used ArcMap 10.0 to calculate the distance from every point count location to landscape attributes including forested (deciduous or coniferous stands) and riparian habitats. Tree stands and riparian habitat were identified with Northwest ReGAP landcover data (http://gap.uidaho.edu/ index.php/nw-gap/land-cover) from 2011, and verified with NAIP imagery from 2009. At our sites, riparian habitat from ReGAP consisted of mesic areas with patchy shrubs. In addition to distance variables, we calculated a normalized difference vegetation index (NDVI) and the proportion of forested, riparian, and big sagebrush habitats around all point count locations. We extracted NDVI values that were generated by Aldridge et al. (2011) and Hanser et al. (2011) for the Wyoming Basins Ecoregion, which were created from $250 \mathrm{~m}$ MODIS (Moderate Resolution Imaging Spectroradiometer) satellite imagery (http://modis.gsfc.nasa.gov/) between May and August of 2004. These NDVI values represent relative NDVI among point count locations during the sage-grouse nesting and brood-rearing season. Topography with greater surface roughness had the potential to create topographic structures (e.g., hilltops, knolls, and cliff edges) that could provide vantage points for avian predators. Riley et al. (1999) created a topographic ruggedness index (TRI) to describe the roughness of landscapes, quantified as the difference in elevation among adjacent pixels of a digital 
elevation map averaged over a user-defined area. For every point count location, we used ArcMap 10.0 to extract TRI values generated by Aldridge et al. (2011) and Hanser et al. (2011). Proportion of habitat (big sagebrush, forested, and riparian), NDVI, and TRI variables were constructed at four spatial extents $\left(0.23-\mathrm{km}^{2}, 0.92-\mathrm{km}^{2}, 3.14-\mathrm{km}^{2}\right.$, and $28.26-\mathrm{km}^{2}$ ) by using a moving window analysis within $0.27-\mathrm{km}, 0.54-\mathrm{km}, 1.00-\mathrm{km}$, and $3.00-\mathrm{km}$ radii, respectively (Aldridge et al. 2011, Hanser et al. 2011).

Euclidean distance is not a good measure of habitat selection by wildlife, because the response of a species to landscape attributes or anthropogenic features often declines as distance increases (Carpenter et al. 2010, Aldridge et al. 2011, Fedy and Martin 2011, Hanser et al. 2011). Thus, we calculated distance decay functions to allow for nonlinear avoidance of landscape attributes or anthropogenic features, expressed as:

Decay function $=\exp ^{\text {(Euclidean distance to feature }(\mathrm{km}) / \text {-decay distance })}$.

We calculated all decay functions with three decay distances $(0.25 \mathrm{~km}, 0.50 \mathrm{~km}$, and $1.00 \mathrm{~km})$. The value of the $0.25-, 0.50-$, and $1.00-\mathrm{km}$ decay functions approached 0 at $\sim 1.2, \sim 2.4$, and $\sim 4.5 \mathrm{~km}$, respectively. The distance at which decay function values approached 0 approximated the home range size of Golden Eagles and ravens (Boarman and Heinrich 1999, DeLong 2004). Decay functions scaled distance variables between 0 and 1 , with greater values corresponding to point count locations closer to landscape attributes or anthropogenic features.

\section{Data Analyses}

We fit multinomial logistic regression models with maximum likelihood using function multinom in package nnet version 7.3-4 in R ( R 2.14.2; R Development Core Team 2012) to evaluate habitat selection of nesting and brood-rearing sage-grouse hens. In addition to our full analysis, we conducted the same analysis with the exclusion of anthropogenic features on a subset of random and sage-grouse locations that were at least 3 $\mathrm{km}$ away from oil and gas structures, communication towers, power lines, rural houses, and major roads. This analysis was intended to verify whether sage-grouse response to avian predators was consistent regardless of influences from anthropogenic structures. Multinomial logistic regression models have been used to model habitat selection of wildlife species with $>2$ response categories (McCracken et al. 1998, McDonald et al. 2006, Bañuelos et al. 2008). We categorized point count locations into four response categories: (1) random, (2) sage-grouse nest, (3) early brood, and (4) late brood. Random point counts were kept in a single category across the summer, because we did not detect differences in avian densities between the first and second half of summer (Dinkins 2013); thus, modeling with multinomial logistic regression was more efficient as we could compare all response categories simultaneously rather than having to conduct a series of binomial regressions. Multinomial logistic regression uses one category as the reference for comparisons with all other categories; thus, each analysis can directly compare all categories among themselves by iteratively changing the reference category in the same model. To compare sage-grouse habitat selection with available sagebrush habitat (random locations), we made comparisons of sage-grouse locations with random locations by coding random locations as the reference category. We then alternated nest and earlybrood location as the reference category to directly compare among sage-grouse locations.

Modeling of sage-grouse habitat selection was conducted using an information-theoretic approach (Anderson 2008). We compared models with Akaike's Information Criterion corrected for small sample sizes $\left(\mathrm{AIC}_{\mathrm{c}}\right)$ and Akaike weights ( $w_{i}$; Burnham and Anderson 2002) using function aictab in package AICcmodavg version 1.25 in R (Mazerolle 2012). We employed sequential $\mathrm{AIC}_{\mathrm{c}}$ modeling of covariate sets (anthropogenic, landscape, and avian predator), which Arnold (2010) suggested as an appropriate approach for identifying and ranking the most parsimonious models. Noninformative covariates $(85 \%$ confidence intervals [CIs] of parameter estimates overlapped 0) were eliminated within each covariate set before comparing top $\mathrm{AIC}_{\mathrm{c}}$-selected models among covariate sets (Arnold 2010). We classified models within $2 \mathrm{AIC}_{\mathrm{c}}$ of the null model as being noncompetitive (Burnham and Anderson 2002); thus, any model within $2 \mathrm{AIC}_{\mathrm{c}}$ of the null was omitted from further analyses.

The best spatial extent and functional form of variables describing the effects of landscape attributes and anthropogenic features on habitat selection by sage-grouse were determined through $\mathrm{AIC}_{\mathrm{c}}$ prior to sequential modeling of covariate sets (Step 1). We did not include WCH or ANTH with any anthropogenic structure variable that was used to create WCH or ANTH. For all distance decay functions, we chose the best decay distance $(0.25 \mathrm{~km}, 0.50 \mathrm{~km}$, and $1.00 \mathrm{~km}$ ) for each distance variable by comparing $\mathrm{AIC}_{\mathrm{c}}$ values. We compared models with individual density, proportion, and TRI variables measured at $0.27-\mathrm{km}$, $0.54-\mathrm{km}, 1.00-\mathrm{km}$, and $3.00-\mathrm{km}$ radii using $\mathrm{AIC}_{\mathrm{c}}$ to choose the best spatial extent for each of those variable groups to be used in the anthropogenic and landscape covariate sets. Density and proportion variables were compared to the analogous proximity variables with $\mathrm{AIC}_{\mathrm{c}}$, and the best functional form of each variable was used in all further modeling (Table 1).

In Step 2, anthropogenic and landscape covariate sets were evaluated sequentially to identify the variables to be included in the best models for each of those covariate sets 
TABLE 1. Variables selected in Step 1 of our modeling process and used in analysis of habitat selection by sage-grouse hens at nest $(n=340)$, early-brood $(n=331)$, and late-brood $(n=121)$ locations at 12 sites in southern Wyoming, USA, 2008-2011. Subscripts indicate best spatial extent or distance decay $(\mathrm{km})$, and descriptions indicate best functional form (see Results).

\begin{tabular}{|c|c|}
\hline Covariate set and variable name & Variable description \\
\hline \multicolumn{2}{|l|}{ Anthropogenic } \\
\hline $\mathrm{OGSden}_{3.0}$ & $\begin{array}{l}\text { Density of oil and gas structures (energy wells, compressor stations, transfer stations, refineries, } \\
\text { and other energy extraction related buildings; no. } \mathrm{km}^{-2} \text { ) }\end{array}$ \\
\hline POWden $_{3.0}$ & Density of power lines $\left(\mathrm{km} \mathrm{km}^{-2}\right)$ \\
\hline MRDden $_{3.0}$ & Density of major roads $\left(\mathrm{km} \mathrm{km}^{-2}\right)$ \\
\hline $\mathrm{HOM}_{1.0}$ & Distance decay function to nearest rural house \\
\hline WCHden $_{1.0}$ & Density of oil and gas structures, communication towers, and houses (no. $\mathrm{km}^{-2}$ ) \\
\hline ANTH $_{0.25}$ & $\begin{array}{l}\text { Distance decay function to nearest oil and gas structure, communication tower, house, or } \\
\text { power line }\end{array}$ \\
\hline \multicolumn{2}{|l|}{ Landscape } \\
\hline SAGEpro $_{1.0}$ & Proportion of big sagebrush (Artemisia spp.) landcover \\
\hline TREE $_{0.25}$ & Distance decay function to nearest forested habitat including deciduous and coniferous stands \\
\hline $\mathrm{RIP}_{1.0}$ & Distance decay function to nearest riparian habitat \\
\hline $\mathrm{TRI}_{0.54}$ & Topographic ruggedness index \\
\hline $\mathrm{NDVI}_{0.27}$ & Normalized difference vegetation index \\
\hline \multicolumn{2}{|l|}{ Avian predator } \\
\hline Small avian predators & $\begin{array}{l}\text { Aggregated density of Black-billed Magpies and American Kestrels calculated from raw point } \\
\text { counts within species-specific effective detection radii (300 m and } 400 \mathrm{~m} \text {, respectively) }\end{array}$ \\
\hline Medium avian predators & $\begin{array}{l}\text { Aggregated density of Common Ravens, Buteo hawks, and Northern Harriers calculated from } \\
\text { raw point counts within species-specific effective detection radii }(600 \mathrm{~m}, 450 \mathrm{~m} \text {, and } 350 \mathrm{~m} \text {, } \\
\text { respectively) }\end{array}$ \\
\hline Large avian predators & $\begin{array}{l}\text { Density of Golden Eagles calculated from raw point counts within the species-specific effective } \\
\text { detection radius of } 1,000 \mathrm{~m}\end{array}$ \\
\hline
\end{tabular}

(i.e. models within $2 \mathrm{AIC}_{\mathrm{c}}$ of the top model within each covariate set). As the final modeling step (Step 3), we compared all top $\mathrm{AIC}_{\mathrm{c}}$-selected models from anthropogenic and landscape covariate sets and the best avian predator model from Dinkins et al. (2012) among each other and as additive models. The avian predator model included three avian predator variables (small, medium, and large avian predators), and three of the four years of data were from Dinkins et al. (2012). The three avian predator variables were constructed by aggregating raw avian predator densities calculated within species-specific EDRs based on the size of the avian predator, which resulted in small (magpie and kestrel), medium (Buteo hawk, harrier, and raven), and large (Golden Eagle) avian predator variables. This avian predator model was shown by Dinkins et al. (2012) to describe potential sage-grouse avoidance of avian predators better than models based on: individual species; distinguishing among different avian predator foraging styles; or avian predator threat to sage-grouse hens, nests, or broods. We based our inference on models within $2 \mathrm{AIC}_{\mathrm{C}}$ of the top selected model (Burnham and Anderson 2002). We prevented multicollinearity by not including in any model any two variables that covaried $(r>0.65)$ as determined with a Pearson's correlation matrix; thus, we eliminated one covarying variable from further analysis by retaining the variable that made the most biological sense.
Although we could not test for spatial autocorrelation in multinomial logistic regressions, avian predator densities derived from distance-sampling techniques were robust to lack of independence of observation locations because distance sampling was set up to be a snapshot in time (Thomas et al. 2010). Our avian predator sampling was designed to count the greatest proportion of the actual number of avian predators within a site each week while not counting the same avian predator more than once per week, as suggested by Ralph et al. (1995) and Thomas et al. (2010). Conducting all point counts within a site in one day reduced the possibility of double-counting individual avian predators during that week's visit. Counting the same individual avian predator during different weeks, regardless of the particular point count location, was properly scaled by accounting for survey effort. We replicated point counts in multiple weeks to increase detection of avian predators (Thomas et al. 2010). When evaluating avian predator densities between sage-grouse and random locations, Dinkins et al. (2012) accounted for spatial autocorrelation in generalized linear mixed models; however, accounting for spatial autocorrelation did not significantly change the coefficient values of their avian predator models. Furthermore, multinomial logistic regression only requires that successive habitat selection choices be independent (Agresti 2007). 
TABLE 2. Multinomial logistic regression models comparing landscape-attribute and anthropogenic-feature variables as covariate sets among locations used by sage-grouse (nest: $n=340$, early-brood: $n=331$, and late-brood: $n=121$ locations) and random locations $(n=660)$ at 12 sites in southern Wyoming, USA, 2008-2011. $K$ is the number of model parameters, $\Delta$ AIC $_{c}$ is the difference from the top model in Akaike's Information Criterion adjusted for small sample size, and $w_{i}$ is the model weight. See Table 1 for variable descriptions.

\begin{tabular}{|c|c|c|c|c|}
\hline Model & $K$ & $\Delta \mathrm{AlC}_{\mathrm{c}}$ & $w_{i}$ & Deviance \\
\hline \multicolumn{5}{|l|}{ Anthropogenic covariate set } \\
\hline OGSden $_{3.0}$, POWden $_{3.0}$, MRDden $_{3.0}, \mathrm{HOM}_{1.0}{ }^{\mathrm{a}}$ & 15 & 0.00 & 0.98 & 3522.16 \\
\hline OGSden $_{3.0}$, POWden $_{3.0}, \mathrm{HOM}_{1.0}$ & 12 & 8.02 & 0.02 & 3536.30 \\
\hline OGSden $_{3.0}$, POWden $_{3.0}$, MRDden $_{3.0}$ & 12 & 17.17 & 0.00 & 3545.44 \\
\hline OGSden $_{3.0}$, MRDden $_{3.0}, \mathrm{HOM}_{1.0}$ & 12 & 19.84 & 0.00 & 3548.12 \\
\hline OGSden $_{3.0}$, POWden $_{3.0}$ & 9 & 20.62 & 0.00 & 3555.00 \\
\hline POWden $_{3.0}$, MRDden $_{3.0}, \mathrm{HOM}_{1.0}$ & 12 & 22.22 & 0.00 & 3550.50 \\
\hline POWden $_{3.0}, \mathrm{HOM}_{1.0}$ & 9 & 27.69 & 0.00 & 3562.06 \\
\hline OGSden $_{3.0}$, MRDden $_{3.0}$ & 9 & 34.02 & 0.00 & 3568.38 \\
\hline POWden $_{3.0}$, MRDden $_{3.0}$ & 9 & 40.72 & 0.00 & 3575.08 \\
\hline POWden $_{3.0}$ & 6 & 42.27 & 0.00 & 3582.70 \\
\hline \multicolumn{5}{|l|}{ Landscape covariate set } \\
\hline SAGEpro $_{1.0}, \mathrm{RIP}_{1.0}, \mathrm{TRI}_{0.54}, \mathrm{NDVI}_{0.27}{ }^{\mathrm{b}}$ & 15 & 0.00 & 0.80 & 3432.84 \\
\hline SAGEpro $_{1.0}, \mathrm{TREE}_{0.25}, \mathrm{RIP}_{1.0}, \mathrm{TRI}_{0.54}, \mathrm{NDVI}_{0.27}$ & 18 & 2.80 & 0.20 & 3429.50 \\
\hline SAGEpro $_{1.0}$, TREE $_{0.25}, \mathrm{RIP}_{1.0}, \mathrm{NDVI}_{0.27}$ & 15 & 16.19 & 0.00 & 3449.02 \\
\hline SAGEpro $_{1.0}, \mathrm{TRI}_{0.54}, \mathrm{NDVI}_{0.27}$ & 12 & 19.05 & 0.00 & 3458.00 \\
\hline SAGEpro $_{1.0}, \mathrm{TREE}_{0.25}, \mathrm{TRI}_{0.54}, \mathrm{NDVI}_{0.27}$ & 15 & 23.25 & 0.00 & 3456.10 \\
\hline SAGEpro $_{1.0}, \mathrm{RIP}_{1.0}, \mathrm{NDVI}_{0.27}$ & 12 & 27.12 & 0.00 & 3466.08 \\
\hline SAGEpro $_{1.0}$, TREE $_{0.25}$, NDVI $_{0.27}$ & 12 & 37.21 & 0.00 & 3476.16 \\
\hline TREE $_{0.25}, \mathrm{RIP}_{1.0}, \mathrm{TRI}_{0.54}, \mathrm{NDVI}_{0.27}$ & 15 & 38.59 & 0.00 & 3471.42 \\
\hline $\mathrm{RIP}_{1.0}, \mathrm{TRI}_{0.54}, \mathrm{NDVI}_{0.27}$ & 12 & 39.71 & 0.00 & 3478.66 \\
\hline SAGEpro $_{1.0}, \mathrm{NDVI}_{0.27}$ & 9 & 44.24 & 0.00 & 3489.30 \\
\hline
\end{tabular}

\section{RESULTS}

\section{Avian Predators, Landscape Attributes, and Anthropogenic Features Analysis}

We conducted 4,441 point count surveys at 1,452 locations during 2008-2011, including 340 sage-grouse nest, 331 sage-grouse early-brood, 121 sage-grouse late-brood, and 660 random locations. These locations were compiled from 289 hens with a mean of 1.2 nests per hen, 2.9 earlybrood locations per hen, and 3.0 late-brood locations per hen. Brood locations were compiled from 124 separate sage-grouse broods from 114 sage-grouse hens. We counted 196 Buteo hawks, 295 Golden Eagles, 77 harriers, 105 kestrels, 143 magpies, and 688 ravens within speciesspecific EDRs (Dinkins et al. 2012), which equated to 248 small, 961 medium, and 295 large avian predators. These counts do not necessarily indicate unique individuals, but rather detections used to quantify density around localized areas. Brood, nest, and random locations aggregated across all years were on average $598.0 \mathrm{~m}$ (38.8 m SE), $908.6 \mathrm{~m}$ (9.6 $\mathrm{m} \mathrm{SE}$ ), and 1,189 m (25.5 m SE) apart, respectively. Avian predator variables did not covary with any other variables $\left(r^{2}<0.02\right.$, variance inflation factor $\left.[\mathrm{VIF}] \leq 2.2\right)$, indicating no multicollinearity between avian predator variables and anthropogenic or landscape feature variables.
During Step 1, our modeling generally suggested that anthropogenic features were influencing sage-grouse habitat selection at a larger spatial extent (3-km radius) than were landscape attributes $(<1-\mathrm{km}$ radius; Table 1$)$. The best spatial extent for density variables was within 3 $\mathrm{km}$ of a point count location. Densities of oil and gas structures $\left(\mathrm{OGSden}_{3.0}\right)$, power lines $\left(\mathrm{POWden}_{3.0}\right)$, and major roads $\left(\operatorname{MRDden}_{3.0}\right)$ fit the data better than raw distance or distance decay functions. The best spatial extents for the proportion of big sagebrush (SAGEpro $\left.{ }_{1.0}\right)$, TRI $\left(\mathrm{TRI}_{0.54}\right)$, and NDVI $\left(\mathrm{NDVI}_{0.27}\right)$ were within $1.00 \mathrm{~km}$, $0.54 \mathrm{~km}$, and $0.27 \mathrm{~km}$, respectively. Distance to rural houses $\left(\mathrm{HOM}_{1.0}\right)$ and riparian habitat $\left(\mathrm{RIP}_{1.0}\right)$ as $1-\mathrm{km}$ distance decay functions fit the data better than Euclidean distance or densities. The effects of $\mathrm{HOM}_{1.0}$ and $\mathrm{RIP}_{1.0}$ on sage-grouse selection of nesting and brood locations became negligible beyond approximately $4 \mathrm{~km}$ (i.e. $1 \mathrm{~km}$ distance decay approaches zero at approximately $4 \mathrm{~km}$ away from an object of interest).

During Step 2 of sequential modeling, we found that sage-grouse selection of nest and brood locations was partially based on landscape attributes and anthropogenic features (Table 2). The top $\mathrm{AIC}_{\mathrm{c}}$-selected anthropogenic feature model $\left(w_{i}=0.98\right)$ included OGSden ${ }_{3.0}$, POWden $_{3.0}$, MRDden 3.0 , and $\mathrm{HOM}_{1.0}$ (Table 2). The top $\mathrm{AIC}_{\mathrm{c}}$-selected 
TABLE 3. Multinomial logistic regression models comparing anthropogenic and landscape covariate sets (top models from Table 2) and the avian predator model (including small, medium, and large avian predator densities) among locations used by sage-grouse (nest, early-brood, and late-brood locations) and random locations at 12 sites in southern Wyoming, USA, 20082011. $K$ is the number of model parameters, $\Delta A I C_{c}$ is the difference from the top model in Akaike's Information Criterion adjusted for small sample size, and $w_{i}$ is the model weight.

\begin{tabular}{lrrrr}
\hline Model & $K$ & $\Delta \mathrm{AIC}_{\mathrm{c}}$ & $w_{i}$ & Deviance \\
\hline Avian, anthropogenic, landscape $^{\mathrm{a}}$ & 36 & 0.00 & 1.00 & 3042.14 \\
Avian, landscape & 24 & 38.24 & 0.00 & 3105.42 \\
Avian, anthropogenic & 24 & 141.46 & 0.00 & 3208.62 \\
Avian & 12 & 203.45 & 0.00 & 3295.24 \\
Anthropogenic, landscape & 27 & 295.98 & 0.00 & 3356.92 \\
Landscape & 15 & 347.16 & 0.00 & 3432.84 \\
Anthropogenic & 15 & 436.48 & 0.00 & 3522.16 \\
Intercept only & 3 & 509.13 & 0.00 & 3619.12
\end{tabular}

${ }^{\mathrm{a}} \mathrm{AIC}_{\mathrm{c}}=3116.01$.

landscape feature model $\left(w_{i}=0.80\right)$ included SAGEpro ${ }_{1.0}$, $\mathrm{RIP}_{1.0}, \mathrm{NDVI}_{0.27}$, and $\mathrm{TRI}_{0.54}$ (Table 2). During Step 3 of sequential modeling, our analyses indicated that sagegrouse hen selection of nest and brood locations was best described by small, medium, and large avian predator densities (avian predator model) in conjunction with many landscape attributes and anthropogenic features $\left(w_{i}=1.00\right.$; Table 3). This indicates that sage-grouse respond to multiple factors related to habitat quality, including factors related to perceived predation risk (landscape attributes and anthropogenic features) and direct predation risk (avian predator densities).

Greater densities of small, medium, and large avian predators were negatively correlated with sage-grouse nest, early-brood, and late-brood locations compared with random locations (Table 4). Early-brood and late-brood sage-grouse locations had lower avian predator densities than nesting sage-grouse locations (Table 5). Within each reproductive stage, sage-grouse locations had similar negative coefficient values for small and medium avian predators, but exhibited greater negative coefficient values for large avian predators (Golden Eagles) compared with small and medium avian predators (Tables 4 and 5).

In general, sage-grouse responded to most anthropogenic features by avoiding them, regardless of the sagegrouse's reproductive stage; however, many of these effects had parameter estimates with 95\% CI that overlapped zero for all reproductive stages (Tables 4 and 5). In contrast to the avoidance of other anthropogenic structures, our analyses indicated that early-brood and late-brood sagegrouse were closer to rural houses $\left(\mathrm{HOM}_{1.0}\right.$ parameter estimate was positive) compared with random locations and nest locations (Tables 4 and 5). We found that nesting, early-brood, and late-brood sage-grouse were in areas with lower OGSden 3.0 compared with random locations (Table 4). However, the effect of $\mathrm{OGSden}_{3.0}$ on sage-grouse habitat use during nesting had a parameter estimate with 95\% CI that overlapped zero (Table 4). Sage-grouse use of habitat was negatively associated with MRDden $_{3.0}$ during all reproductive stages, with 95\% CI of parameter estimates overlapping zero for brood locations (Table 4). Early-brood and late-brood sage-grouse locations had lower POWden $_{3.0}$ compared with random locations (Table 4).

For landscape attribute variables, we found that sagegrouse differed in their response to proximity to riparian habitat $\left(\mathrm{RIP}_{1.0}\right)$ depending on their reproductive stage. Compared with random locations, sage-grouse selected nest locations farther away from riparian habitat (RIP 1.0 parameter estimate was negative), but early-brood sagegrouse neither selected nor avoided habitat based on

TABLE 4. Parameter estimates with $95 \%$ confidence intervals ( $L C L$ and $U C L$ ) from top $A_{I} C_{c}$-selected multinomial logistic regression models (Tables 2 and 3). This analysis compares either nest, early-brood, or late-brood locations used by sage-grouse with random (reference category) locations at 12 sites in southern Wyoming, USA, 2008-2011. See Table 1 for variable descriptions.

\begin{tabular}{|c|c|c|c|c|c|c|c|c|c|}
\hline \multirow[b]{2}{*}{ Variable } & \multicolumn{3}{|c|}{ Nest vs. random } & \multicolumn{3}{|c|}{ Early-brood vs. random } & \multicolumn{3}{|c|}{ Late-brood vs. random } \\
\hline & Estimate (SE) & $\mathrm{LCL}$ & UCL & Estimate (SE) & $\mathrm{LCL}$ & UCL & Estimate (SE) & $\mathrm{LCL}$ & UCL \\
\hline te & $7.83(0.91)$ & -9.61 & $-6.05^{*}$ & $-17.57(1.51)$ & -20.54 & $-14.60^{*}$ & $-18.25(1.98)$ & -22.14 & $-14.35^{*}$ \\
\hline mall avian $p$ & $-0.09(0.03)$ & -0.15 & $-0.02^{*}$ & $-0.34(0.06)$ & -0.47 & $-0.21^{*}$ & $-0.33(0.09)$ & -0.52 & $-0.16^{*}$ \\
\hline Medium avian predator & $-0.08(0.02)$ & -0.12 & $-0.04^{*}$ & $-0.28(0.03)$ & -0.34 & -0.2 & $-0.28(0.05)$ & -0.38 & $-0.19^{*}$ \\
\hline vian predator & $-0.14(0.05)$ & -0.23 & $-0.05^{*}$ & $-0.59(0.12)$ & -0.82 & & $-0.45(0.14)$ & $-c$ & $-0.19^{*}$ \\
\hline OG & $-0.37(0.20)$ & -0.75 & 0.02 & $6(0.24)$ & -1.03 & -0. & $-3.18(1.01)$ & 16 & $-1.20^{*}$ \\
\hline POWden $_{3.0}$ & $0.44(0.67)$ & -0.88 & 1.76 & $-2.52(0.97)$ & -4.44 & $-0.61^{*}$ & $-5.28(1.71)$ & -8.64 & $-1.92^{*}$ \\
\hline $\mathrm{HOM}_{1.0}$ & $0.12(0.84)$ & -1.53 & 1.76 & $2.16(0.79)$ & 0.59 & $3.73^{*}$ & $2.56(0.99)$ & 0.62 & $4.50^{*}$ \\
\hline MRDden $_{3.0}$ & $-2.99(1.31)$ & -5.58 & $-0.41^{*}$ & $-1.52(1.48)$ & -4.44 & 1.40 & $-2.00(2.54)$ & -7.01 & 3.02 \\
\hline SAGEpro $_{1.0}$ & $3.42(0.58)$ & 2.28 & $4.55^{*}$ & $2.17(0.59)$ & 1.02 & $3.33^{*}$ & $1.21(0.78)$ & -0.32 & 2.75 \\
\hline $\mathrm{RIP}_{1.0}$ & $-0.86(0.28)$ & -1.42 & $-0.31^{*}$ & $-0.26(0.29)$ & -0.83 & 0.31 & $0.85(0.40)$ & 0.05 & $1.64^{*}$ \\
\hline $\mathrm{TRI}_{0.54}$ & $-0.04(0.01)$ & -0.05 & $-0.02 *$ & $-0.02(0.01)$ & -0.03 & $-0.01^{*}$ & $0.02(0.01)$ & -0.04 & $<0.00^{*}$ \\
\hline $\mathrm{NDVI}_{0.27}$ & $6.72(1.06)$ & 4.62 & $8.81^{*}$ & $5.97(1.11)$ & 3.78 & $8.16^{*}$ & $9.00(1.36)$ & 6.32 & $11.68^{*}$ \\
\hline
\end{tabular}

* Denotes a 95\% confidence interval that does not include zero. 
TABLE 5. Parameter estimates with $95 \%$ confidence intervals ( $L C L$ and $U C L)$ from top $A I C_{c}$-selected multinomial logistic regression models (Tables 2 and 3). The reference category was alternated from random to nest or early-brood location to facilitate direct comparison of locations used by sage-grouse at 12 sites in southern Wyoming, USA, 2008-2011. See Table 1 for variable descriptions.

\begin{tabular}{|c|c|c|c|c|c|c|c|c|c|}
\hline \multirow[b]{2}{*}{ Variable } & \multicolumn{3}{|c|}{ Early-brood vs. nest $^{a}$} & \multicolumn{3}{|c|}{ Late-brood vs. nest ${ }^{a}$} & \multicolumn{3}{|c|}{ Late-brood vs. early-brood ${ }^{b}$} \\
\hline & Estimate (SE) & $\mathrm{LCL}$ & UCL & Estimate (SE) & $\mathrm{LCL}$ & UCL & Estimate (SE) & $\mathrm{LCL}$ & UCL \\
\hline Intercept & $-9.74(1.56)$ & -12.82 & $-6.66^{*}$ & $-10.42(2.01)$ & -14.38 & $-6.45^{*}$ & $-0.68(2.27)$ & -5.15 & $3.79^{*}$ \\
\hline Small avian predator & $-0.26(0.07)$ & -0.39 & $-0.13^{*}$ & $-0.25(0.09)$ & -0.42 & $-0.07^{*}$ & $0.01(0.10)$ & -0.20 & 0.21 \\
\hline Medium avian predator & $-0.20(0.03)$ & -0.27 & $-0.13^{*}$ & $-0.21(0.05)$ & -0.30 & $-0.11^{*}$ & $0.00(0.05)$ & -0.11 & 0.10 \\
\hline Large avian predator & $-0.45(0.12)$ & -0.69 & $-0.22^{*}$ & $-0.32(0.14)$ & -0.60 & $-0.04^{*}$ & $0.14(0.18)$ & -0.21 & 0.49 \\
\hline OGSden $_{3.0}$ & $-0.19(0.27)$ & -0.72 & 0.33 & $-2.82(1.01)$ & -4.81 & $-0.82^{*}$ & $-2.62(1.01)$ & -4.61 & $-0.63^{*}$ \\
\hline POWden $_{3.0}$ & $-2.97(1.01)$ & -4.94 & $-0.98^{*}$ & $-5.73(1.72)$ & -9.11 & $-2.34^{*}$ & $-2.76(1.76)$ & -6.22 & 0.70 \\
\hline $\mathrm{HOM}_{1.0}$ & $2.04(0.88)$ & 0.32 & $3.78^{*}$ & $2.44(1.05)$ & 0.37 & $4.52^{*}$ & $0.40(0.88)$ & -1.34 & 2.14 \\
\hline MRDden $_{3.0}$ & $1.47(1.71)$ & -1.89 & 4.83 & $0.99(2.68)$ & -4.28 & 6.27 & $-0.48(2.62)$ & -5.64 & 4.68 \\
\hline SAGEpro $_{1.0}$ & $-1.24(0.66)$ & -2.54 & 0.05 & $-2.20(0.83)$ & -3.85 & $-0.56^{*}$ & $-0.96(0.80)$ & -2.54 & 0.62 \\
\hline $\mathrm{RIP}_{1.0}$ & $0.60(0.32)$ & 0.03 & 1.23 & $1.71(0.43)$ & 0.87 & $2.54^{*}$ & $1.11(0.41)$ & 0.30 & $1.91^{*}$ \\
\hline $\mathrm{TRI}_{0.54}$ & $0.02(0.01)$ & 0.00 & $0.04^{*}$ & $0.02(0.01)$ & 0.00 & $0.04^{*}$ & $0.00(0.01)$ & -0.02 & 0.02 \\
\hline $\mathrm{NDVI}_{0.27}$ & $-0.75(1.12)$ & -2.97 & 1.47 & $2.28(1.36)$ & -0.41 & 4.97 & $3.03(1.29)$ & 0.48 & $5.58^{*}$ \\
\hline
\end{tabular}

* Denotes a 95\% confidence interval that does not include zero.

${ }^{a}$ Nest as reference category. This analysis also included random locations; however, those results are in Table 4.

${ }^{b}$ Early-brood as reference category. This analysis also included random and nest locations; however, those results are in the earlybrood vs. nest and late-brood vs. nest columns and Table 4.

proximity to riparian habitat, and late-brood sage-grouse selected locations closer to riparian habitat $\left(\mathrm{RIP}_{1.0}\right.$ parameter estimate was positive; Table 4). However, both early-brood and late-brood locations were closer to riparian habitat compared with nest locations $\left(\mathrm{RIP}_{1.0}\right.$ parameter estimate was positive), and late-brood locations were closer to riparian habitat than early-brood locations $\left(\mathrm{RIP}_{1.0}\right.$ parameter estimate was positive; Table 5). SAGEpro $_{1.0}$ was positively associated with sage-grouse locations during nesting and early brood rearing (Table 4). NDVI was positively associated with sage-grouse locations at all reproductive stages (Table 4). Sage-grouse during all reproductive stages were located in areas with flatter topography $\left(\mathrm{TRI}_{0.54}\right.$ parameter estimates were negative) compared with random locations (Table 4).

\section{Avian Predators and Landscape Attributes Analysis}

Our analysis that excluded locations within $3 \mathrm{~km}$ of anthropogenic structures comprised 2,406 point count surveys at 803 locations during 2008-2011. This equated to 153 sage-grouse nest locations (45\% of total nest data), 207 sage-grouse early-brood locations (63\% of total earlybrood data), 93 sage-grouse late-brood locations (77\% of total late-brood data), and 350 random locations (53\% of total random data). Similar to the full analysis, avian predator variables did not covary with any other variable $\left(r^{2}<0.05\right.$, VIF $\left.\leq 2.3\right)$, indicating no multicollinearity between avian predator variables and anthropogenic or landscape feature variables. The subset analysis illustrated that the pattern of habitat use by sage-grouse was nearly the same as that in our full analysis in relation to avian predator densities and sage-grouse response to landscape attributes (Tables 6 and 7). Unlike in the full dataset, latebrood sage-grouse did not select for SAGEpro S.o $_{1.0}$ or $\mathrm{RIP}_{1.0}$; even so, the coefficients had the same positive values as in the full analysis (Table 7).

\section{DISCUSSION}

Sage-grouse hens used both indirect and direct mechanisms of predator avoidance to select habitat, which may have partially lowered their exposure to predation and nest predation. We did not quantify the effects of olfactory (mammalian) predators on sage-grouse selection of habitat. However, sage-grouse have not been found to hide their nests from olfactory predators at a microhabitat scale (Conover et al. 2010). In general, sage-grouse were located in less risky habitat that was farther away from potential perches and had lower densities of small, medium, and large avian predators. This result is largely concordant with the finding of Dinkins et al. (2012), who included some of the same bird location data but did not include landscape attribute or anthropogenic feature variables. The pattern of lower avian predator densities at sage-grouse locations was consistent between our full analysis and our analysis of locations $>3 \mathrm{~km}$ away from anthropogenic structures (Tables 3 and 4 compared with Tables 6 and 7), which provided additional evidence that sage-grouse used direct predator avoidance. We found that sage-grouse locations were best described with models that included multiple habitat variables and avian predator densities. This implies that information on avian predator 
TABLE 6. Multinomial logistic regression models comparing landscape-attribute variables and then comparing the top model from the landscape covariate set with the avian predator model (small, medium, and large avian predator densities) among locations used by sage-grouse (nest: $n=153$, earlybrood: $n=207$, and late-brood: $n=93$ locations) and random locations $(n=350)$ at 12 sites in southern Wyoming, USA, 20082011. Sage-grouse and random locations were greater than 3 $\mathrm{km}$ from anthropogenic features. $K$ is the number of model parameters, $\Delta \mathrm{AIC}_{\mathrm{c}}$ is the difference from the top model in Akaike's Information Criterion adjusted for small sample size, and $w_{i}$ is the model weight. See Table 1 for variable descriptions.

\begin{tabular}{lllll}
\hline Model & $K$ & $\Delta \mathrm{AIC}_{\mathrm{c}}$ & $w_{i}$ & Deviance \\
\hline
\end{tabular}

Landscape covariate set

SAGEpro ${ }_{1.0}, \mathrm{RIP}_{1.0}, \mathrm{TRI}_{0.54}$ $\mathrm{NDVI}_{0.27}^{\mathrm{a}}$

SAGEpro $_{1.0}, \mathrm{TRI}_{0.54}, \mathrm{NDVI}_{0.27}$

SAGEpro $_{1.0}, \mathrm{RIP}_{1.0}, \mathrm{NDVI}_{0.27}$

SAGEpro $_{1.0}, \mathrm{NDVI}_{0.27}$

$\mathrm{RIP}_{1.0}, \mathrm{TRI}_{0.54}, \mathrm{NDVI}_{0.27}$

$\mathrm{RIP}_{1.0}, \mathrm{NDVI}_{0.27}$

$\mathrm{TRI}_{0.54}, \mathrm{NDVI}_{0.27}$

SAGEpro ${ }_{1.0}$, RIP $_{1.0}$

SAGEpro $_{1.0}, \mathrm{RIP}_{1.0}, \mathrm{TRI}_{0.54}$

$\mathrm{NDVI}_{0.27}$

Avian and landscape comparison

Avian, landscape ${ }^{b}$

Avian

Landscape

Intercept only

${ }^{\mathrm{a}} \mathrm{AIC}_{\mathrm{c}}=1961.57$.

${ }^{\mathrm{b}} \mathrm{AIC}_{\mathrm{c}}=1764.93$.

use of sagebrush habitat, even sagebrush habitat little influenced by anthropogenic structures, could improve understanding of how sage-grouse are distributed in sagebrush habitat.

Sage-grouse exhibit high individual (among seasons) and generational site fidelity (Fisher et al. 1993, Holloran and Anderson 2005, Thompson 2012), which likely limits their ability to move in response to changing distributions of avian predators. Site fidelity has been suggested to delay nonuse patterns of sage-grouse in response to developing oil and gas fields, with older birds displaying strong fidelity despite low productivity and yearling birds (first nesting season) avoiding new anthropogenic structures (Holloran et al. 2010, Naugle et al. 2011). Older sage-grouse hens with failed nests in a previous nesting season had lower nest site fidelity compared with hens with successful nests (i.e. eggs hatched), but the average distances between their sequential nests were $512 \mathrm{~m}$ and $283 \mathrm{~m}$, respectively, hardly landscape-level movements (Holloran and Anderson 2005). Distances between sequential nests from our study also indicated lower nest-site fidelity for hens with previously failed nests compared with hens with successful nests, especially when stratified by sites with low vs. high raven density (average distance to previously failed nests: $0.66 \mathrm{~km}[0.26 \mathrm{~km} \mathrm{SE}]$ and $1.16 \mathrm{~km}[0.20 \mathrm{~km} \mathrm{SE}]$, respectively; average distance to previously hatched nests: $0.53 \mathrm{~km}[0.20 \mathrm{~km} \quad \mathrm{SE}]$ and $0.36 \mathrm{~km}[0.08 \mathrm{~km} \mathrm{SE}]$, respectively; Dinkins 2013). The greatest average distance between subsequent nests was for birds with previously failed nests in areas with comparatively higher raven density. Yearling birds seem to adjust spatial location at relatively large spatial extents, whereas older birds changed spatial location at smaller scales.

Rather than indirect and direct predator avoidance explaining our results, sage-grouse habitat use patterns could also be explained by areas of relatively greater predation over time leading to low sage-grouse productivity (i.e. sage-grouse disappear from a localized area, resembling nonuse by sage-grouse). It is plausible that our random locations were areas with greater avian predator densities associated with historically lower productivity for sage-grouse. Temporal stability in location of nesting structures for avian predators in sagebrush habitat could generate areas with greater predation risk for sage-grouse. However, stability also correlates with relatively constant spatial habitat use by avian predators, which might allow

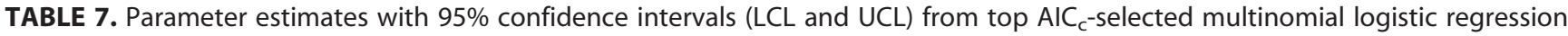
models (Tables 6). This analysis compares either nest, early-brood, or late-brood locations used by sage-grouse at 12 sites in southern Wyoming, USA, 2008-2011, with random (reference category) locations. See Table 1 for variable descriptions.

\begin{tabular}{|c|c|c|c|c|c|c|c|c|c|}
\hline \multirow[b]{2}{*}{ Variable } & \multicolumn{3}{|c|}{ Nest vs. random } & \multicolumn{3}{|c|}{ Early-brood vs. random } & \multicolumn{3}{|c|}{ Late-brood vs. random } \\
\hline & Estimate (SE) & $\mathrm{LCL}$ & UCL & Estimate (SE) & $\mathrm{LCL}$ & $\mathrm{UCL}$ & Estimate (SE) & $\mathrm{LCL}$ & UCL \\
\hline te & $-7.83(1.25)$ & -10.60 & -5.6 & $-20.30(2.30)$ & -24.83 & $-15.77^{*}$ & $-19.98(2.46)$ & -24.82 & $-15.13^{*}$ \\
\hline Small & $-0.09(0.05)$ & -0.18 & $<0.00^{*}$ & $-0.43(0.10)$ & -0.62 & -0 & $-0.45(0.12)$ & -0.69 & $-0.21^{*}$ \\
\hline Medium avian predator & $-0.06(0.03)$ & -0.11 & $<0.00^{*}$ & $-0.30(0.05)$ & -0.39 & $-0.21 *$ & $-0.29(0.06)$ & -0.40 & $-0.18^{*}$ \\
\hline Large avian predator & $-0.13(0.07)$ & -0.26 & 0.01 & $-0.73(0.20)$ & -1.13 & $-0.34^{*}$ & $-0.40(0.14)$ & -0.69 & $-0.12^{*}$ \\
\hline SAGEpro $_{1.0}$ & $3.65(0.80)$ & 2.07 & $5.23^{*}$ & $2.22(0.74)$ & 0.76 & $3.68^{*}$ & $0.29(0.91)$ & -1.50 & 2.07 \\
\hline $\mathrm{RIP}_{1.0}$ & $-0.85(0.42)$ & -1.67 & $-0.03^{*}$ & $-0.06(0.38)$ & -0.81 & 0.68 & $0.59(0.49)$ & -0.38 & 1.56 \\
\hline $\mathrm{TRI}_{0.54}$ & $-0.03(0.01)$ & -0.04 & $-0.01^{*}$ & $-0.02(0.01)$ & -0.03 & $<0.00^{*}$ & $-0.03(0.01)$ & -0.05 & $-0.01^{*}$ \\
\hline $\mathrm{NDVI}_{0.27}$ & $6.53(1.50)$ & 3.57 & $9.50 *$ & $6.01(1.52)$ & 3.02 & $8.99 *$ & $12.94(1.72)$ & 9.56 & $16.32^{*}$ \\
\hline
\end{tabular}

* Denotes a 95\% confidence interval that does not include zero. 
sage-grouse to directly avoid them. Even small distance adjustments in sequential nest locations have the potential to move a sage-grouse outside of a corvid's or a raptor's home range or use hotspots. Lower nest-site fidelity of sage-grouse illustrates the capacity of sage-grouse to at least partially adjust their use of habitat by moving away from threats after nest failure. Our results indicate that sage-grouse habitat use patterns were likely a remnant of multiple factors. Predator avoidance (indirect and direct mechanisms) and localized disappearance of sage-grouse were unlikely to be mutually exclusive processes shaping habitat use patterns of sage-grouse.

Avian predators including Buteo hawks (MacLaren et al. 1988, Schroeder et al. 1999, Schroeder and Baydack 2001), Golden Eagles (MacLaren et al. 1988, Danvir 2002), harriers (Schroeder et al. 1999, Thirgood et al. 2000, Fletcher et al. 2003), kestrels (Schroeder et al. 1999), magpies (Holloran and Anderson 2003, Vander Haegen et al. 2002), and ravens (Manzer and Hannon 2005, Bui et al. 2010, Coates and Delehanty 2010) negatively affect nest success or potentially prey on sage-grouse adults and chicks. One of the responses of prey species to the presence of these predators is direct avoidance (Lima 1998, Evans 2004, Cresswell 2008, Dinkins et al. 2012). Similarly to the results of Dinkins et al. (2012), our analyses indicated that sage-grouse avoided avian predators during all reproductive stages-nesting, early brood, and late brood-but at different magnitudes. Our results also suggest that sage-grouse hens have the ability to distinguish among threats to their own survival, their nests, and their offspring.

Sage-grouse are a relatively long-lived bird (Connelly et al. 2011). Johnson and Braun (1999) and Taylor et al. (2012) found that adult survival was the most influential demographic parameter on sage-grouse population growth, followed by chick survival and then nest success. Golden Eagles have been identified as the primary predator of adult sage-grouse (Schroeder et al. 1999, Schroeder and Baydack 2001, Mezquida et al. 2006). Sage-grouse hens avoided Golden Eagles (large avian predators) at greater magnitudes than smaller avian predators within each reproductive stage (i.e. more strongly negative parameter estimates for large avian predators than for small and medium avian predators when comparing sage-grouse locations to random locations; Table 4), suggesting that sage-grouse hens were predominantly concerned with their own survival. Our results also indicated that the magnitudes of avian predator avoidance for predators of all sizes were greater at early-brood and late-brood locations than at nest locations, suggesting that broods moved in a way that reduced predation risk to both adults and chicks.

In addition to direct avoidance of avian predators, sagegrouse selected habitat in response to landscape attributes and anthropogenic features. Direct and indirect avoidance of avian predators were not necessarily linked (correlated) from the perspective of a sage-grouse, because indirect cues (perches and areas with food subsidies for predators) were not correlated with the density of any avian predator species $\left(r^{2}<0.02\right)$. Similarly to previous research, our analyses confirmed that sage-grouse select locations farther away from landscape attributes that could be used as perches or provide subsidized food resources for predators, including oil and gas structures (Aldridge 2005, Holloran 2005, Walker et al. 2007, Doherty 2008, Holloran et al. 2010, Kirol 2012) at all reproductive stages, power lines at brood locations, and major roads (Holloran 2005, Aldridge and Boyce 2007) and riparian habitat (Doherty et al. 2010, Dzialak et al. 2011) at nest locations. Sage-grouse also chose flatter locations, similarly to findings by Doherty et al. (2010), Dzialak et al. (2011), and Kirol (2012). A greater proportion of big sagebrush and higher NDVI values were positively associated with sage-grouse locations. Greater proportion of sagebrush habitat has been positively correlated with abundance of sagebrush-obligate and associated birds including Brewer's Sparrows, Green-tailed Towhees (Pipilo chlorurus), sagegrouse, Sagebrush Sparrows, and Sage Thrashers (Oreoscoptes montanus; Knick et al. 2005, Noson et al. 2006, Aldridge et al. 2011). Sage-grouse population growth and recruitment have also been associated with a greater NDVI (Blomberg et al. 2012); however, Guttery et al. (2013) did not find a connection between NDVI values and sagegrouse chick survival.

Habitat use involves tradeoffs among risks of weather exposure and predation and benefits of food acquisition (Verdolin 2006). Similarly to the findings of Dzialak et al. (2011), our results confirmed that sage-grouse have opposing associations with riparian habitat depending on reproductive stage. Sage-grouse were farther away from riparian habitat compared with random locations while nesting, but were closer to it compared with random locations during late brood rearing. Nesting may have occurred away from riparian areas because concealment cover and lower predator abundance was more important than food availability for nesting sage-grouse hens. However, chicks have increasing energetic needs as they grow, and sage-grouse hens typically move broods to riparian areas after early brood rearing (Crawford et al. 2004, Gregg and Crawford 2009). Sage-grouse hens also move broods to align with changes in food availability as the breeding season progresses. Riparian habitats provide forbs and invertebrates that meet the energetic demands of growing sage-grouse chicks (Connelly et al. 2004, Aldridge and Boyce 2007, Dzialak et al. 2011), but riparian habitats have a higher risk of brood failure (Aldridge and Boyce 2007). Sage-grouse appear to minimize the negative effects of increased predation risk associated with riparian areas directly by avoiding avian predators and indirectly by 
avoiding riparian habitat during relatively more vulnerable reproductive stages (nest and early brood). Sage-grouse early-brood and late-brood locations were closer to rural houses than random and nest locations, which may be explained by the distribution of rural houses in more productive sagebrush habitat. This is speculative and deserves more research. If rural houses are in better habitat for brood foraging, sage-grouse movements to these areas may show similar patterns as movements to riparian habitat.

A prey species' ability to predict and avoid risky habitat increases survival and reproductive success, but the ability to directly avoid predators is more beneficial than avoiding indirect cues of predation risk (Thomson et al. 2006). Both mechanisms presumably achieve reduced predation rates; however, there may be other population-limiting effects as a result of indirect and direct predator avoidance, such as reduced foraging ability of prey species in areas of lower habitat quality (Lima 1998, Evans 2004, Cresswell 2008). High densities of avian predators and close proximity to landscape attributes and anthropogenic features-specifically riparian habitat, rugged topography, oil and gas infrastructure, power lines, and major roads-are likely to result in reduced adult survival and higher predation of sage-grouse eggs and chicks. Sage-grouse use of habitat was negatively associated with avian predator densities, with quality sage-grouse habitat presumably having lower densities of small, medium, and large avian predators. Increased avian predator abundance may induce changes in sage-grouse behavior associated with habitat usage. Thus, human manipulation of habitat that promotes increased densities of avian predators may limit sagegrouse populations, because even habitat that has highquality cover and forage may become functionally unavailable to sage-grouse as avian predator densities increase.

\section{ACKNOWLEDGMENTS}

Research funding was provided by the Anadarko Petroleum Corporation, Jack H. Berryman Institute, Lincoln County Predator Management Board, Predatory Animal District of Sweetwater County, School of Energy Resources at the University of Wyoming, South Central and Southwest Wyoming Sage-grouse Local Working Groups, Utah Agricultural Experiment Station (Utah State University, publication number 8718), Uinta County Predator Management Board, Wyoming Animal Damage Management Board, and Wyoming Game and Fish Department. We greatly appreciate the logistical support provided by N. Tratnik, T. Christiansen, M. Zornes, N. Hymas, T. Clayson, M. Holloran, D. Oles, L. Oles, F. Blomquist, C. Morton, L. McCarthy, C. Powell, R. Etzelmiller, M. Murry, and many others. We thank our many field technicians, who are too numerous to name. We would also like to give a special thanks to the cooperation of the many landowners throughout southwestern and south-central Wyoming for allowing access to private lands.

\section{LITERATURE CITED}

Agresti, A. (2007). An Introduction to Categorical Data Analysis, second edition. John Wiley and Sons, Hoboken, NY, USA.

Aldridge, C. L. (2005). Identifying habitats for persistence of Greater Sage-Grouse (Centrocercus urophasianus) in Alberta, Canada. Ph.D. dissertation, University of Alberta, Edmonton, Canada.

Aldridge, C. L., and M. S. Boyce (2007). Linking occurrence and fitness to persistence: Habitat-based approach for endangered Greater Sage-Grouse. Ecological Applications 17:508526.

Aldridge, C. L., S. E. Hanser, S. E. Nielsen, M. Leu, B. S. Cade, D. J. Saher, and S. T. Knick (2011). Detectability adjusted count models of songbird abundance. In Sagebrush Ecosystem Conservation and Management: Ecoregional Assessment Tools and Models for the Wyoming Basins (S. E. Hanser, M. Leu, S. T. Knick, and C. L. Aldridge, Editors), Allen Press, Lawrence, KS, USA, pp. 141-220.

Anderson, D. R. (2008). Model Based Inference in the Life Sciences: A Primer on Evidence. Springer, New York.

Arnold, T. W. (2010). Uninformative parameters and model selection using Akaike's Information Criterion. Journal of Wildlife Management 74:1175-1178.

Bañuelos, M., M. Quevedo, and J. Obeso (2008). Habitat partitioning in endangered Cantabrian Capercaillie Tetrao urogallus cantabricus. Journal of Ornithology 149:245-252.

Blomberg, E. J., J. S. Sedinger, M. T. Atamian, and D. V. Nonne (2012). Characteristics of climate and landscape disturbance influence the dynamics of Greater Sage-Grouse populations. Ecosphere 3:art55. http://dx.doi.org/10.1890/ES11-00304.1

Boarman, W. I. (1993). When a native predator becomes a pest: A case study. In Conservation and Resource Management (S. K. Majumdar, E. W. Miller, D. E. Baker, E. K. Brown, J. R. Pratt, and R. F. Schmalz, Editors), Pennsylvania Academy of Science, Easton, PA, USA, pp. 191-206.

Boarman, W. I., and B. Heinrich (1999). Common Raven (Corvus corax). In The Birds of North America 476 (F. B. Gill and A. Poole, Editors), Academy of Natural Sciences, Philadelphia, PA, USA, and American Ornithologists' Union, Washington DC, USA.

Boarman, W. I., R. J. Camp, M. Hagan, and W. Deal (1995). Raven abundance at anthropogenic resources in the western Mojave Desert, California. Report to Edwards Air Force Base, California. National Biological Service, Riverside, CA, USA.

Bradley, L. C., and D. B. Fagre (1988). Coyote and bobcat responses to integrated ranch management practices in south Texas. Journal of Range Management 41:322-327.

Braun, C. E. (1998). Sage grouse declines in western North America: What are the problems? Proceedings of the Western Association of State Fish and Wildlife Agencies 78:139-156.

Buckland, S. T., D. R. Anderson, K. P. Burnham, J. L. Laake, D. L. Borchers, and L. Thomas (2001). Introduction to Distance Sampling: Estimating Abundance of Biological Populations. Oxford University Press, New York.

Bui, T. D., J. M. Marzluff, and B. Bedrosian (2010). Common Raven activity in relation to land use in western Wyoming: 
Implications for Greater Sage-Grouse reproductive success. The Condor 112:65-78.

Burnham, K. P., and D. R. Anderson (2002). Model Selection and Multimodel Inference: A Practical Information-Theoretic Approach, second edition. Springer-Verlag, New York.

Carpenter, J., C. L. Aldridge, and M. S. Boyce (2010). Sage-grouse habitat selection during winter in Alberta. Journal of Wildlife Management 74:1806-1814.

Chalfoun, A. D., and T. E. Martin (2009). Habitat structure mediates predation risk for sedentary prey: Experimental tests of alternative hypotheses. Journal of Animal Ecology 78: 497-503.

Coates, P. S., and D. J. Delehanty (2010). Nest predation of Greater Sage-Grouse in relation to microhabitat factors and predators. Journal of Wildlife Management 74:240-248.

Coates, P. S., K. B. Howe, M. L. Casazza, and D. J. Delehanty (2014). Landscape alterations influence differential habitat use of nesting buteos and ravens within sagebrush ecosystem: Implications for transmission line development. The Condor: Ornithological Applications 116. In press.

Connelly, J. W., C. A. Hagen, and M. A. Schroeder (2011). Characteristics and dynamics of Greater Sage-Grouse populations. Studies in Avian Biology 38:53-67.

Connelly, J. W., S. T. Knick, M. A. Schroeder, and S. J. Stiver (2004). Conservation Assessment of Greater Sage-Grouse and Sagebrush Habitats. Unpublished Report, Western Association of Fish and Wildlife Agencies, Cheyenne, WY, USA.

Conover, M. R., J. S. Borgo, R. E. Dritz, J. B. Dinkins, and D. K. Dahlgren (2010). Greater Sage-Grouse select nest sites to avoid visual but not olfactory predators. The Condor 112: 331-336.

Crawford, J. A., R. A. Olson, N. E. West, J. C Mosley, M. A. Schroeder, T. D. Whitson, R. F. Miller, M. A. Gregg, and C. S. Boyd (2004). Ecology and management of sage-grouse and sage-grouse habitat. Journal of Range Management 57:2-19.

Cresswell, W. (2008). Non-lethal effects of predation in birds. Ibis 150:3-17.

Danvir, R. E. (2002). Sage Grouse Ecology and Management in Northern Utah Sagebrush-Steppe. Deseret Land and Livestock Wildlife Research Report, Deseret Land and Livestock Ranch and the Utah Foundation for Quality Resource Management, Woodruff, UT, USA.

DeLong, J. P. (2004). Effects of Management Practices on Grassland Birds: Golden Eagle. Northern Prairie Wildlife Research Center, Jamestown, ND, USA.

Dinkins, J. D. (2013). Common Raven density and Greater SageGrouse nesting success in southern Wyoming: Potential conservation and management implications. Ph.D. dissertation, Utah State University, Logan, UT, USA.

Dinkins, J. D., M. R. Conover, C. P. Kirol, and J. L. Beck (2012). Greater Sage-Grouse (Centrocercus urophasianus) select nestsites and brood-sites away from avian predators. The Auk 129:600-610.

Doherty, K. E. (2008). Sage-grouse and energy development: Integrating science with conservation planning to reduce impacts. Ph.D. dissertation, University of Montana, Missoula, MT, USA.

Doherty, K. E., D. E. Naugle, and B. L. Walker (2010). Greater SageGrouse nesting habitat: The importance of managing at multiple scales. Journal of Wildlife Management 74:15441553.
Dzialak, M. R., C. V. Olson, S. M. Harju, S. L. Webb, J. P. Mudd, J. B. Winstead, and L. D. Hayden-Wing (2011). Identifying and prioritizing Greater Sage-Grouse nesting and brood-rearing habitat for conservation in human-modified landscapes. PLoS ONE 6:e26273. doi:10.1371/journal.pone.0026273

Evans, K. L. (2004). The potential for interactions between predation and habitat change to cause population declines of farmland birds. Ibis 146:1-13.

Fedy, B., and K. Martin (2011). The influence of fine-scale habitat features on regional variation in population performance of alpine White-tailed Ptarmigan. The Condor 113:306-315.

Fisher, R. A., A. D. Apa, W. L. Wakkinen, K. P. Reese, and J. W. Connelly (1993). Nesting-area fidelity of Sage Grouse in southeastern Idaho. The Condor 95:1038-1041.

Fletcher, Q. E., C. W. Dockrill, D. J. Saher, and C. L. Aldridge (2003). Northern Harrier (Circus cyaneaus) attacks on Greater Sage-Grouse (Centrocercus urophasianus) in southern Alberta. Canadian Field-Naturalist 117:479-480.

Frey, S. N., and M. R. Conover (2006). Habitat use by mesopredators in a corridor environment. Journal of Wildlife Management 70:1111-1118.

Ghalambor, C. K., and T. E. Martin (2000). Parental investment strategies in two species of nuthatch vary with stage-specific predation risk and reproductive effort. Animal Behaviour 60: 263-267.

Giesen, K. M., T. J. Schoenberg, and C. E. Braun (1982). Methods for trapping Sage Grouse in Colorado. Wildlife Society Bulletin 10:224-231.

Gilbert, M. M., and A. D. Chalfoun (2011). Energy development affects populations of sagebrush songbirds in Wyoming. Journal of Wildlife Management 75:816-824.

Gregg, M. A., and J. A. Crawford (2009). Survival of Greater SageGrouse chicks and broods in the northern Great Basin. Journal of Wildlife Management 73:904-913.

Guttery, M. R., D. K. Dahlgren, T. A. Messmer, J. W. Connelly, K. P. Reese, P. A. Terletzky, N. Burkepile, and D. N. Koons (2013). Effects of landscape-scale environmental variation on Greater Sage-Grouse chick survival. PLOS One 8:e65582. doi:10.1371/ journal.pone.0065582

Hanser, S. E., C. L. Aldridge, M. Leu, M. M. Rowland, S. E. Nielsen, and S. T. Knick (2011). Greater Sage-Grouse: General use and roost site occurrence with pellet counts as a measure of relative abundance. In Sagebrush Ecosystem Conservation and Management: Ecoregional Assessment Tools and Models for the Wyoming Basins (S. E. Hanser, M. Leu, S. T. Knick, and C. L. Aldridge, Editors), Allen Press, Lawrence, KS, USA, pp. 112-140.

Holloran, M. J. (2005). Greater Sage-Grouse (Centrocercus urophasianus) population response to natural gas field development in western Wyoming. Ph.D. dissertation, University of Wyoming, Laramie, WY, USA.

Holloran, M. J., and S. H. Anderson (2003). Direct identification of northern sage-grouse (Centrocercus urophasianus) nest predators using remote sensing cameras. Canadian Field-Naturalist 117:308-310.

Holloran, M. J., and S. H. Anderson (2005). Spatial distribution of Greater Sage-Grouse nests in relatively contiguous sagebrush habitats. The Condor 107:742-752.

Holloran, M. J., R. C. Kaiser, and W. A. Hubert (2010). Yearling Greater Sage-Grouse response to energy development in Wyoming. Journal of Wildlife Management 74:65-72. 
Howe, K. B., P. S. Coates, and D. J. Delehanty (2014). Selection of anthropogenic features and vegetation characteristics by nesting Common Ravens in the sagebrush ecosystem. The Condor: Ornithological Applications 116:35-49.

Johnson, K. H., and C. E. Braun (1999). Viability and conservation of an exploited sage-grouse population. Conservation Biology 13:77-84.

Kirol, C. P. (2012). Quantifying habitat importance for Greater Sage-Grouse (Centrocercus urophasianus) population persistence in an energy development landscape. M.S. thesis, University of Wyoming, Laramie, WY, USA.

Knick, S. T., A. L. Holmes, and A. F. Miller (2005). The role of fire in structuring sagebrush habitats and bird communities. Studies in Avian Biology 30:1-13.

Lammers, W. M., and M. W. Collopy (2007). Effectiveness of avian predator perch deterrents on electric transmission lines. Journal of Wildlife Management 71:2752-2758.

Lima, S. L. (1998). Nonlethal effects in the ecology of predatorprey interactions. BioScience 48:25-34.

MacLaren, P. A., S. H. Anderson, and D. E. Runde (1988). Food habits and nest characteristics of breeding raptors in southwestern Wyoming. Great Basin Naturalist 48:548-553.

Manzer, D. L., and S. J. Hannon (2005). Relating grouse nest success and corvid density to habitat: A multi-scale approach. Journal of Wildlife Management 69:110-123.

Martin, T. E., and J. V. Briskie (2009). Predation on dependent offspring: A review of the consequences for mean expression and phenotypic plasticity in avian life history traits. Annals of the New York Academy of Sciences 1168:201-217.

Mazerolle, M. J. (2012). Package 'AICcmodavg', version 1.25. R Foundation for Statistical Computing, Vienna. www.R-project. org

McCracken, M. L., B. F. J. Manly, and M. Vander Heyden (1998). The use of discrete-choice models for evaluating resource selection. Journal of Agricultural, Biological, and Environmental Statistics 3:268-279.

McDonald, T. L., B. F. J. Manly, R. M. Nielson, and L. V. Diller (2006). Discrete-choice modeling in wildlife studies exemplified by Northern Spotted Owl nighttime habitat selection. Journal of Wildlife Management 70:375-383.

Mezquida, E. T., S. J. Slater, and C. W. Benkman (2006). Sagegrouse and indirect interactions: Potential implication of coyote control on sage-grouse populations. The Condor 108: 747-759.

Naugle, D. E., K. E. Doherty, B. L. Walker, M. J. Holloran, and H. E. Copeland (2011). Energy development and Greater SageGrouse. Studies in Avian Biology 38:489-503.

Noson, A. C., R. A. Schmitz, and R. F. Miller (2006). Influence of fire and juniper encroachment on birds in high elevation sagebrush steppe. Western North American Naturalist 66: 343-353.

Prather, P. R., and T. A. Messmer (2010). Raptor and corvid response to power distribution line perch deterrents in Utah. Journal of Wildlife Management 74:796-800.

Ralph, C. J., S. Droege, and J. R. Sauer (1995). Managing and Monitoring Birds using Point Counts: Standards and Applications. USDA Forest Service General Technical Report PSWGTR-149.
R Development Core Team (2012). R: A Language and Environment for Statistical Computing, version 2.14.2. R Foundation for Statistical Computing, Vienna. www.R-project. org

Riley, S. J., S. D. DeGloria, and R. Elliot (1999). A terrain ruggedness index that quantifies topographic heterogeneity. Intermountain Journal of Sciences 5:1-4.

Schroeder, M. A., and R. K. Baydack (2001). Predation and the management of prairie grouse. Wildlife Society Bulletin 29: 24-32.

Schroeder, M. A., C. L. Aldridge, A. D. Apa, J. R. Bohne, C. E. Braun, S. D. Bunnell, J. W. Connelly, P. A. Deibert, S. C. Gardner, M. A. Hilliard, G. D. Kobriger, et al. (2004). Distribution of sage grouse in North America. The Condor 106:363-376.

Schroeder, M. A., J. R. Young, and C. E. Braun (1999). Sage Grouse (Centrocercus urophasianus). In The Birds of North America 425 (F. B. Gill and A. Poole, Editors), Academy of Natural Sciences, Philadelphia, PA, USA, and American Ornithologists' Union, Washington DC, USA.

Slater, S. J., and J. P. Smith (2010). Effectiveness of raptor perch deterrents on an electrical transmission line in southwestern Wyoming. Journal of Wildlife Management 74:1080-1088.

Taylor, R. L., B. L. Walker, D. E. Naugle, and L. S. Mills (2012). Managing multiple vital rates to maximize Greater SageGrouse population growth. Journal of Wildlife Management 76:336-347.

Thirgood, S. J., S. M. Redpath, P. Rothery, and N. J. Aebischer (2000). Raptor predation and population limitation in Red Grouse. Journal of Animal Ecology 69:504-516.

Thomas, L., S. T. Buckland, E. A. Rexstad, J. L. Laake, S. Strindberg, S. L. Hedley, J. R. B. Bishop, R. A. Marques, and K. P. Burnham (2010). Distance software: Design and analysis of distance sampling surveys for estimating population size. Journal of Applied Ecology 47:5-14.

Thompson, T. R. (2012). Dispersal ecology of Greater SageGrouse in northwestern Colorado: Evidence from demographic and genetic methods. Ph.D. dissertation, University of Idaho, Moscow, ID, USA.

Thomson, R. L., J. T. Forsman, F. Sardà-Palomera, and M. Mönkkönen (2006). Fear factor: Prey habitat selection and its consequences in a predation risk landscape. Ecography 29: 507-514.

U.S. Department of Agriculture (2010). 2009 NAIP Survey: Summary Report. Farm Service Agency, Aerial Photography Field Office, Salt Lake City, UT, USA.

Vander Haegen, W. M., M. A. Schroeder, and R. M. DeGraaf (2002). Predation on real and artificial nests in shrubsteppe landscapes fragmented by agriculture. The Condor 104:496506.

Verdolin, J. L. (2006). Meta-analysis of foraging and predation risk trade-offs in terrestrial systems. Behavioral Ecology and Sociobiology 60:457-464.

Wakkinen, W. L., K. P. Reese, J. W. Connelly, and R. A. Fischer (1992). An improved spotlighting technique for capturing Sage Grouse. Wildlife Society Bulletin 20:425-426.

Walker, B. L., D. E. Naugle, and K. E. Doherty (2007). Greater SageGrouse population response to energy development and habitat loss. Journal of Wildlife Management 71:2644-2654. 